\title{
Science, Technology and Sustainable Food Production in Africa: An Assessment
}

\author{
Maurice Ayodele Coker ${ }^{1,2}$ \\ Eugenia Member George-Genyi2 \\ Tabitha Venenge Agishi² \\ Gabriel T. Abumbe ${ }^{3}$ \\ ${ }^{1}$ Department of Political Science, University of Calabar, Calabar \\ ${ }^{2}$ Benue State University, Makurdi, Benue State \\ ${ }^{3}$ Ph.D Graduate, Department of Political Science, University of Uyo, Uyo
}

\section{Doi:10.5901/mjss.2015.v6n6s4p285}

\begin{abstract}
This paper examines the impact of science and technology on sustainable food security in Africa, particularly on the contribution of Biodiversity, Biotechnology, and Biosafety. The researchers adopted a descriptive survey of wide range of literature drawn from the experience of South Africa, Zimbabwe, Uganda, Kenya, Cameroon, Tanzania and Nigeria. The centrality of the role of science and technology in sustainable food security in these countries is highlighted. Challenges of achieving sustainable food security is also identified. The study concludes that to achieve sustainable food security Africa must lay a solid foundation for African science and technology by investing more on education, research and development (R\&D) as well as initiate public policies aimed at sharing adaptive and practical innovations and breakthroughs in science, technology and sustainability of food in the African continent among African States. Furthermore, African countries as a matter of urgency should invest on agricultural development with a view to achieving sustainable food production.
\end{abstract}

Keywords: Science; technology; sustainable development; food security; food production, biodiversity; biotechnology; biosafety.

\section{Introduction}

This study examines the role of science and technology on agricultural performance with a view to achieving a sustainable food security for the African people. It is incontrovertible fact that Food, after Air and Water is a basic necessity for human existence. Nobody can subsist for long without adequate and nourishing food intake. Hence, its production in sustainable quality and quantity is taken to be a major preoccupation of the human race. Its inadequacy poses serious public policy problem. According to SciDev Net (21/02/3), "Nearly 200 million Africans, most of them children, are undernourished. These people lack 'food security'; they do not have access at all times to enough food to lead active, healthy lives." To address this problem, Gordon Conway and Gary Toenniessen of the Rockefeller Foundation; cited in SciDev Net expressed the view that adopting intensively genetic and agro-ecological technologies is likely to sustain agricultural productivity in Africa. The role of science and technology on enhancing rapid and sustainable agricultural productivity is an imperative for Africa.

Rademacher (2015) has argued that food crises in the sub-Saharan Africa was perceived to emanate from inadequate supply of food, hence a strategy of making food available for donor countries was adopted. That is, "the problem was not lack of food but an inability on the part of both local and international actor to distribute food it is most needed in timely and cost effective manor". Climate change and economic crises were identified as influencing food production on the continent. Therefore, Rademacher (2015) suggested that there was a need to look beyond the food supply box with a view to discerning alternative solutions. There is no gainsaying the fact that, the problem of achieving sustainable food production in Africa is partially hinged on her mode of production. Most of Africa still largely adopt the traditional and primitively self-sustaining agricultural production. The adopting of modern or contemporary scientific and technological innovations by farmers (which are essentially small-scale) are very insignificant when compared to the number of farmers and size of the land involved. Yet, the productive capacities of most African farmers is not largely achieve sustainable food production.

Science and technology innovations has largely offered the likely solution to this problem. Acquiring and adopting the needed and relevant innovations to Africa poses a number of questions. These include: Does Africa have the 
enabling environments (economic, political, cultural and psychological) on which transferred science and technology innovations to thrive?; to what extent can the available science and technology innovation assist sustainable food production in Africa without perceived negative impact?; and, what should be done to adapt current state of scientific and technological innovations meet the food production needs of the continent?

The study seeks to explore these questions in order to provide possible answers to them. Also, this enable the understanding of the food crisis in Africa, well as highlight what is being done in some sub-Saharan Africa to tackle food shortages specifically, by engaging scientific and technological knowledge I agricultural production?

\section{Statement of the Problem}

Food production, and availability or non-availability on a sustainable scale has continued to generate copious debates among students, scholars, stakeholders and policy makers as to defining, assessing and recommending the best path/s to achieving sustainable food security on the continent. The path of adopting science, technology and innovation has been chosen by most countries worldwide as the quicker and result-oriented strategy to achieve this objective. Indeed, Ozor and Urama (2013) have argued that there exists diverse technologies that could warrant food security in Africa. "These technologies range from mechanical technology to biological and biochemical technology as well as indigenous technology options" (Ozor and Urama, 2013).

Expatiating further on our subject matter, the executive summary on Rosegrant's et al., 2020 Discussion Paper of the International Food Policy Research Institute encapsulates the central problem of this paper in the following words:

Food security in Africa has substantially worsened since 1970. Although the proportion of malnourished individuals in Sub-Saharan Africa has remained in the range of 33-35 percent since around 1970, the absolute number of malnourished people in Africa has increased substantially with population growth, from around 88 million in 1970 to an estimate of over 200 million in 1999-2001 (Rosegrant et al., 2005: x).

In view of the above, one is tended to attempt finding out the extent to which science and technology can address this problem. The role of science, technology and innovation in securing food security for Africa was clearly emphasized in Bartel's Executive Summary of the United Nations Conference on Trade and Tariff (UNCTAD) 2010, Technology and Innovation Report- Enhancing Food Security in Africa. According to the Summary, "the report, focuses on challenges of improving agricultural performance in Africa and the role of technology and innovation in raising agricultural production and incomes of all farmers, including smallholder farmers, including smallholder farmers" (UNCTAD 2011, ix). This is against the backdrop that of Africa in order to improve food security achieve broader economic growth and development the need for strengthening the innovation capabilities of her agricultural must be properly addressed.

(http://www.atdforum.org/journal/htm/2009.34/11/: 1of 15). Indeed. The Report (2010) posited pessimistically that the "Sub-Saharan Africa is the developing region most likely to miss the first Millennium Development Goal (MDG1), aiming to reduce by half extreme hunger and poverty by 2015" (Bartel; Summary of UNCTAD Technology and Innovation Report, 2010 -http://www.atdforum.org/journal/htm/2009.34/11/: 1of 21). This is because "that per-capita food production had not only been on the decline since the early 1970s, but has been stagnating over the last three and half decades ago" (Bartel, Summary of UNCTAD Report: 2010: 2 of 21).

To achieve food production sustainability, technological innovation is indorsed adoption for the continent, since its "... ability to adapt ... a significant step in technological empowerment ... over a period of time, can lead to the creation of knowledge generation capabilities among actors (that) are demand-driven rather than those that aim to replicate the successes of the other regions around the world ...."(Bartel: Summary of UNCTAD Report: 2010: 3 of 21). It is argued that agricultural innovations should be such that it synergizes "economic and non-economic actors, and the linkages among these actors, and technological, organizational and social learning about the kind needed to devise contextspecific solutions," the report emphasized (Bartel: Summary of UNCTAD Report, 2010). The central problem identified by the Report (20100 is whether the dissemination of existing technology innovations from outside African can promote its agriculture. It suggested that for the achievement of such technological breakthroughs in African agricultural development, an enabling framework to support its emergence becomes an imperative. Precisely, because it is likely to strengthen existing linkages, promote new linkages and foster inter-organizational learning leading to capital accumulation and technological change. To achieve desire policy outcome, it is expected that such enabling environment is such that strengthens the adsorptive capacity of local actors through a protective policy which 'recognizes their legal rights and privileges, linkages, and socio-cultural norms and historical context. These would also address such constraining factors as declining investment; land tenure and credit access; a focus on small farmers; adapting to climate change; bio energy; and, structural policy reforms (See Report, 2010: 4-10). Consequently, an agricultural innovations systems approach is recommended as the policy thrust for improved food security in Africa. It is expected that 
'agricultural development strategies that incorporate the main components of the AIS approach can be transformed into a workable concept at the country level'. That is, by identifying the key actors and linkages that together strengthen knowledge flows and enabling interactive learning. (For details of the main sources of linkages, see .Bartel: Summary of UNCTAD 2010: 12 of 21).

Surmising on agriculture and food security, the Report observes that "achieving food security means much more than simply producing more food" (Bartel: Summary of UNCTAD 2010: 13 of 21). Indeed, the Report (UNCTAD, 2010) identifies four main ways to improve local food production; namely: expanding arable land; achieving higher levels of cropping intensity; increasing yields; and, implementing agricultural policy reforms. To achieve each of the above, several challenges are also identified: imminent soil degradation due to among other's climate change; desertification in northern part on the continent which put a large number of the population at risk; massive migration into the cities with it the concomitant transfers of potentially available force in the cities; and, these migrations not only weakened the local productive capacities, but can slow and even reverse the expectations of the 'interventions to improve the attractiveness of agriculture and rural livelihoods' (UNCTAD, 2010: 15).

Other constraints include: excessive use, and diversion of arable land for biofuels and live stocks and production of animal feed to have tended to exacerbate the dire food scarcity, and persistent decreasing food availability in Africa; and, inadequate financial resources and investments. Above all, inappropriate and indiscriminate transfer and application of science and technology innovations from the western developed countries to the developing countries of Africa. The appropriateness and systematic application or otherwise, of science and technology to improve agricultural production is likely to determine largely Africa's food security capability. It is against this background that the study, attempts to examine the extent to which science; technology had impacted on food security in Africa.

The relevance of Science and Technology (S\&T) to the sustainable food production in any society has taken a central position in public policy-making and implementation worldwide. This interest, and increasing concern had risen in response to both the growing awareness; and, fear about the environmental degradation initiated by rapid industrialization as well as the increasing pressures on resource demands resulting from population growth. It is envisaged that due to the two major factors mentioned above, efforts should be made to increase food production to meet future needs among the population must not only efficiently, but effectively with minimum inputs. The development and application of innovations in science and technology become very significant if Africa desires to achieve sustainable food security. The concept Sustainability implies the "attempts to achieve simultaneously the goals of an improved environment, a better economy and a just and participative society, rather than trading off any one of these against the other" (George, 2010; cited in Illesanmi, 2010, Coker et al., 2013). Coker et al., (2013) further enthused that sustainable development that is socio-ecologically focused, is the ability to fulfill "human needs while maintaining the quality of the natural environment indefinitely" (Jiboye, 201; cited in Coker et al., (2013). Sustainability in food production is a major problem of Africa. There are a number of reasons for this problem has been explored in this study, alongside suggested solutions. One of these solutions is the systematic application of appropriate Science and Technology innovations to Agriculture in Africa.

Africa's demographic profile is one of the most rapid population growths, as each new age group contained more people than the one before it, Thus, even if individual African couples choose to have fewer children than their parents, Africa's population will continue to grow because there are now more men and women of child-bearing age than ever before (Kegler, 2007:350). With 8 to 10 billion people expected to live upon the earth and consume what can be consumed on it in the 21 century, the possibility has arisen that there could not be enough food to feed the world. If so, food scarcity will lead to famine and mass starvation, and countries will engage in "food fights" over agricultural products.

Given this trend of rapid population and systematic destruction of the earth's ecosystem which is needed to feed the world, the question is can the earth still sustain human beings? For most optimists, science and technology through genetically engineered crops to revolutionize farming, preserve the diversity in Africa's tropical forest, and feed future generation. The central question which this study seeks to verify is to ascertain the extent to which science and technology in the agricultural revolution can provide food security to the teeming population of Africa?

\section{Literature Review}

To enable the understanding of our subject matter, a cursory review of relevant variables in what follows is undertaken. This seeks to explore explicitly the extant views and supposition of students, scholars, policy makers and other stakeholders on the subject of study, in order to systematically reposition the nexus among them; particularly articulate the role of science, technology and innovation on achieving sustainable food security in Africa. 


\subsection{Understanding Science}

The word "science" takes a very definitive position in this study. Science encompasses two basic ideas: namely as body of knowledge or a method of study". In fact, the term Science, (from a Latin word Scientia; meaning "knowledge) is "a systematic enterprise that builds and organizes knowledge in the form of testable explanations and predictions about the universe." (What is Engineering Science: http://www.engineering-science.org/wp-content/themes/iesc/pdf/activity_report/ ppt_material_3.pdf?). Francis Bacon coined the term "Science" to imply the acquisition of knowledge is through the scientific method by experiments and observations, which may take the form of scientific facts, scientific models, or scientific theories. It refers to a way of pursuing knowledge that seek to explain the phenomena of the material universe (Wikipedia).

Collaborating this view of meaning of "science", the Science Council, reiterate that "Science is the pursuit of knowledge and understanding of the natural and social world following a systematic methodology based on evidence." David Edgerton, professor at the history of science and technology at Imperial College, define Science as" a pursuit, an activity, related to the creation of new knowledge, rather than established knowledge itself...as well as a species of research" which aims at defining "the nature of the knowledge not the means of its creation only"

(http://www.3.mperial.ac.uk/historyofscience/aboutthecentre/staff/professordavidedgerton: 1).

The above conceptualizations of "Science" is accepted as providing the groundswell for this study. Indeed, scientific enterprise alongside technology, and innovation has tended to play tremendous role in synergising agricultural revolution toward achieving sustainable food security worldwide. Africa cannot be an exception to this phenomenal artefact of human contrivance. Its formulation and application is sufficiently demonstrated in sundry science and technology policy of African countries over the years.

\subsection{Understanding technology}

The concept "technology" like science may be variously understood. For instance, technology may be taken "as that form of cultural activity, devoted to the production or transformation of material objects or the creation of procedural systems in order to expand the realm of practical human possibility" (Lukpata et al., 2014). Its' input consists of raw or already processed materials and bodies of information; its characteristic internal or transforming resources are know-how (methods, procedure and techniques) and knowledge of properties of its input's resources; its characteristic's nonintellectual resources include: "energy, information, tools and perceptual and neuromuscular skills" (Lukpata et al., 2014) In short, technology is the application of scientific and other organized knowledge to solve practical tasks in the society.

Although science and technology have been defined differently, they are both regarded as part of a single methodology. Bruno Latour calls this unified institution "technoscience" (Latour 1987). The term "Technoscience" was coined by French Philosopher Gaston Bachelard in 1953 (Hottois, 1984; Latour, 1987; Latour, 1979). Accordingly, "technoscience is the technological and social context of science .... (It) " recognises that scientific knowledge is not only socially coded and historically situated but (are) sustained and made durable by material (non-human) networks" (Wikipedia, https://en.wikipedia.org/wiki/Technoscience: 1 of 4).

Furthermore, Technoscience states that the fields of science and technology are linked and $/ \mathrm{g}$ mrow together, and scientific knowledge requires an infrastructure of techn/vvology in order to remain stationary or move forward (Wikipedia, https://en.wikipedia.org/wiki/Technoscience: 1 of 4).

Science, Technology and Innovation are related in number of ways. This is succinctly captured in a paper titled: "The Relationship between Science, Technology and Society", published in honour of Nathan Rosenburg as follows:

... (1) new knowledge which serves as a direct source of ideas for new technological possibilities; (2) source of tools and techniques for more efficient engineering design and a knowledge base for evaluation of feasibility of designs; (3) research instrumentation, laboratory techniques and analytical methods used in research that eventually find their way into design or industrial practices, often through intermediate disciplines; (4) practice of research as a source for development and assimilation of new human skills and capabilities eventually useful for technology; (5) creation of a knowledge base that becomes increasingly important in the assessment of technology in terms of its wider social and environmental impacts; (6) knowledge base that enables more efficient strategies of applied research, development, and refinement of new technologies (Abstract: Research Policy, Vol 23 Issue 5, 1994, pp 477 -486; cited in http://www.sciencedirect.com/science/article/pii/0048733394010013)

Despite these linkages, we can distinguish between science and technology in terms of the aim. The aim of science is the acquisition of knowledge of reality through scientific procedure based on the criterion of truth. On the other hand, the first aim of technology is the transformation of reality motivated and appraised by such different criteria as 
usefulness, profitability or aesthetics. Science, as the sum of knowledge, is objective and neutral with respect to the reality examined.

\title{
3.3 Understanding Food Security
}

A serious problem of sustainable livelihood confronting citizens of most developing societies is that of food security. Food Security is a situation in which all people, at all times, have physical and economic access to sufficient, safe and nutritious food to meet their dietary needs and food preferences for an active healthy life (Mwaniki, 2005:1 citing IFPRI (International Food Policy Research Institute,. 2002).

Mwaniki (2005) commenting on this condition observes that, even though "achieving food security in its totality continues to be a challenge" for the developing nations; it is also a problem for the developed world. Mwaniki however, pointed out that these

\begin{abstract}
... difference(s) lies in the magnitude of the problem in terms of its severity and proportion of the population affected. In developed nations the problem is alleviated by providing targeted food security interventions, including food aid in the form of direct food relief, food stamps, or indirectly through subsidized food production (2005:1, retrieved from http://zunia.org/sites/defaultfiles/media/nodefiles/ac/157163_Achieving\%2520Food\%2520Security\%...).
\end{abstract}

The food security interventionist programmes initiated by governments of developed countries, alongside conscious development and application of science, technology and innovation has tended to make the difference in assessing food for their citizens with those of the developing ones. Food security has three aspects: namely; "food availability, food access and food adequacy" (Rosegrant et al, 2005). To Mwaniki (2005), food availability implies that the supply of food should be in sufficient quantity, and access to food should be on demand. In fact, food access must be adequate not only in quality but also in quantity, and quality. For Mwaniki, it should ensure an adequate consistent and dependable supply of energy and nutrients through sources that are affordable and socio culturally acceptable to them at all times.

It has been observed that over seventy percent of African population are food in-secured (Andersen, 2002). The situation is so acute for rural dwellers because food is produced by only "small holder's farmers, which make up over $90 \%$ of the continent's food supply. The rest of the food unsecured population consists of landless poor in the rural areas (30\%) and the urban poor. Because over $70 \%$ of the poor live in rural areas, where also the largest population of food insecure live. It is evident that we cannot significantly and sustainably reduce food insecurity without transforming the living condition of these areas. The pertinent question then is, how can African continent achieve food security?

The solution lies in increasing food availability, food access and food adequacy for all. Sometimes this involves adopting new technologically developed means of agricultural production as already explained. However, because the food insecurity is directly correlated with poverty, it is necessary not only alleviate poverty but also create wealth for the largest population. The key lies in mutual honest intention from multi-stakeholders to ensure that all is done with the sole purpose of benefiting them.

Notwithstanding all of the above the role of science and technology in facilitating sustainable food security in Africa is central to this study.

\section{Interface between Science, Technology and Food Security}

To assess the interface between science, technology and food security in Africa, it is pertinent to discuss its major components and their ramifications for Africa food security as follows:

\subsection{Biodiversity}

Biodiversity or biological diversity is an umbrella term that refers to the earth's variety of life. Technically, it encompasses three basic levels of organization in living systems; genetic diversity, species diversity, and ecosystem diversity. Until recently, public attention has been focused exclusively on preserving species diversity, including old-growth forests, tall grass prairies, wetland's coastal habitats and coral reef. A good example of this trend is the Cross River State of Nigeria programme of conservation of natural forest.

Forest, especially tropical forests in Africa, are important to preserving biodiversity because they are home to countless species of animal and plants, many of them still unknown (Kegler, 2007:387). However, destruction of tropical 
forest, where two-third to three-fourth of all species are believed to live, threatens the destruction of much of world's undiscovered biological diversity and genetic heritage. Overwhelming alarming evidence indicates that the destruction of tropical forest, which resulted to environmental deterioration is destroying a wide range of living organisms in Africa (Kegler, 2007:385). In 2004, a scientific study predicted that global warming could drive to extinction up to thirty-seven per-cent all living species by mid-21 $1^{\text {st }}$ century (Gugliotta, 2004:6). Another study ominously concluded that "current extinction rates are 100-1000 times higher than prehuman levels, and predicted losses of habitat from land conservation will probably push this rate higher still (Wri, 2006, www.wn.org/trends, Jan. 7). How had science and technology tackled this problem?

According to Kegler (2007:386), the rapid growth of biotechnology has made it possible for the preservation of the earth's biological diversity so as to maintain a wide gene pool from which to develop new medical and agricultural products. MNCs in the Global North are major players in the so called "enclosure movement" geared to privatize and mechanize the products derived from plants and animal genes that are the genetic basis for sustained life. In India, for example, the products of a neem trees have been used for medicines, contraception, toiletries, timber, fuel and insecticides. In 1985, the US and Japanese firms began patenting a variety of neem compounds that India never patented. Now local Indian population must compete with MNCs for neem derived products, often at sharply higher prices.

\subsection{Biotechnology}

Biotechnology according to the UN Convention on Biological Diversity is "use of living systems and organisms to develop or make products, or any technological application that uses biological systems, living organisms or derivatives thereof, to make or modify products or processes for specific use" (Article 2: https//www.cbd.int/convention/text). With regards to Africa the application of the Convention is confronted with a number of challenges, (as highlighted in the study on Status of Agricultural Biotechnology and Biosafety Regulatory Systems in East Africa, by Agricultural Biotechnology Research and Development) includes:

1. Lack of a strong and clear regulatory framework, both legal and operational guidelines and these calls for finalizing National Biotechnology Policies and legal frameworks.

2. High regulatory costs.

3. Inadequate sustainable financial support

4. Low research and regulatory capacity both human and infrastructural capacity ... (http://www.biovisioneastafrica.com/publications/status_biosafety_biotech.pdf).

There is no gainsaying that despite these challenges biotechnology has contributed to increasing food production in Africa. This paper also examines the contribution of biotechnology to food production on the continent.

\subsection{Biosafety}

Biosafety is the "prevention of large-scale loss of biological integrity, focusing on ecology and human health" (Wikipedia: https://en.wikipedia.org/\%3Ftitle\%3DBiosafety). Accordingly, it is used to prevent us from harmful incidents; which may include the "possibilities of bioterrorism acts or release of harmful chemicals and or organisms into the environment" (https://en.wikipedia.org/\%3Ftitle\%3DBiosafety). Indeed, biosafety encompasses a range of measures, policies and procedures for minimizing potential risks that biotechnology may pose to the environment and human health (https://www.cbd.int/doc/press/presskits/bs/cpbs-unep-cbd-en.pdf).

Despite the obvious benefits of modern technology, Article $8(\mathrm{~g})$ of the Convention for Biological Diversity (CBD), has cautioned on the risks involved. Hence it has enjoined all signatories to:

Establish or maintain means to regulate, manage or control the risks associated with the use and release of living modified organisms resulting from biotechnology which are likely to have adverse environmental impacts that could affect the conservation and sustainable use of biological diversity, taking into account the risks to human health (Clark et. al:2002; 10; Clarke et al 2005:7).

Essegbey and Strokes (1998) have noted two types of risks "associated with the continued use biotechnological process and intermediate products in laboratories; namely: potential risks and uncertainty about the impact of biotechnological products when released into the wider environment" (cited in Norman Clark, 2005 et al: 10; Clark et al 2007: 7).

It is against the backdrop of these risks that many nations around the world have put in place biosafety measures to curtail its negative impact; particularly resulting from the consumption of biotechnological products. The Biosafety 
guidelines, biosafety framework and the National Biosafety Committee (NBC) itself were all created by the National Council of Science and Technology (NCST) under the legal authority of the Science and Technology Act of 1980 ( See: Nang'ayo, 2006; Harsh, 2005). Kebeba (2012) notes that the signatories to the Cartagena protocol on biosafety to the UN convention on Biological Diversity agreed to establish institutions that safeguard the safe "handling of GMOs or living modified organisms (LMOs) within countries and their transfer across national boundaries". With effect from 11 September, 2003, the protocol became legally binding on at least 50 countries that had ratified it. Furthermore, in the Sub-Sahara Africa, only South Africa and Zimbabwe have introduced biosafety legislation. Cameroon, Cote d'voire, and Kenya, Nigeria and Uganda are still in the legislative process. The remaining countries are either in the process or have yet to start developing their biosafety framework (Kebeba, 2012).

\section{Relevance of Science and Technology to Africa}

The role of biotechnology in Africa must be understood against the backdrop of African growing population vis-à-vis food production. Ndiritu (2007) notes that at the growth rate of 3.1 per cent, the population of Africa which was 200 million 30 years ago, is about 520 million today. Ndiritu projects it to increase to 1.3 billion in the next 25 years; Africa having the highest growth rate in the world. He further added that, "this present and growing population makes it difficult to maintain adequate food consumption levels". For example, "although global food production has reached a stage where sufficient food" is produce "to meet the needs of every person on earth, the per-capita food production and availability" had, and still remain low in Africa (Ndiritu, 2007).

In many parts of Africa, biotechnology has improved agriculture. Alhassan, (2003), posits that "several uncontroversial tools of modern biotechnology are already in use, such as tissue culture, molecular breeding, diagnostics and modern recombinant vaccine production". He pointed out that through the use of tissue culture, vast quantities of clean vegetative propagated planting materials can be produced as clones from a particular plant tissue. This is the widely applied biotechnology tool in Africa at the moment". So far, genetic modification (GM) biotechnology has to date gained importance in countries such as Egypt, Kenya, South Africa and Zimbabwe. In Kenya, for example, the application of tissue culture technology has been initiated in different crops and has resulted in increased production of banana, pyrethrum, potato, cassava, sugar cane and flowers, most of which have become commercial enterprises (Doyle and Persley 1996:74).

Ndititu corroborated the utility of biotechnology in Agricultural development in the following words:

The use of DNA-based molecular markers is now applied in various forms to construct linkage maps of different species. This helps locate particular genes of relevance to the rapid improvement of crop and livestock breeding in Africa (2003:112).

According to Ndiritu (2003), these techniques "are applicable to many African crop improvement programs such as those seeking to enhance resistance to diseases (for example, maize streak virus) or to generate tolerance to insect pests and drought conditions". For instance, "specific programs and capacities" have discovered to assist "resistance to maize stem borer and drought tolerance".

In addition, certain genetically modified crops resistant to "pesticides, insects, and diseases have been initiated in order to reduce "the prohibitive costs to farmers of agricultural chemical inputs and yield losses". In fact, Ndiritu (2002) is optimistic that Africa will achieve food security, poverty alleviation, and environmental conservation by "using crops that have a high yield, and resistance to pesticides, insects, and diseases. Great strides are being made in the use of genetic engineering".

Furthermore, Ndirtu (2003) posits that recombinant animal vaccines have considerable application in Africa to combat rampant and devastating livestock diseases such as tinder pest and rift valley fever, and that many laboratories in Africa are presently involved in the generation and application of these technologies. In the study and control of human, animal and plant diseases, Including HIVIAID5, tinder pest, and streak and mosaic viruses of different crops. Biotechnology, therefore, has a tremendous potential. In the improvement of agriculture and food production in Africa. Qualm's (1999) extant analysis on the impact of pathogen-free banana in sub-Sahara Africa, shows for the larger farms that an average yield increases $93 \%$ can be anticipated, and this may increase to $150 \%$ for small holders.

\section{Science, Technology and Sustainable Food Production in Africa}

Science, technology and innovations have tended to impact positively in a number of ways on sustainable food production in Africa. Essiet (2014) rightly notes that "tracking the challenges of malnutrition and food security and improving production to create jobs require rethinking of how food is produced, distributed and consumed" through 
science, technology and innovation researches. Therefore, the question on how to achieve this desire was addressed during the 2014 Conference by Food and Technology Department of the Federal Institute of Industrial Research Oshodi (FIIRO), Nigeria. The conference was attended by "over 120 dignitaries from the academia, research institutes, Nigeria Institute of Food and Science and Technology (NIFST). The forum agreed that to achieve the aim of sustainable food production, appropriate value to agriculture produce must added by "using simple processing technologies that can be adopted by micro, small and medium scale entrepreneurs for production of different convenient foods"(Essiet, 2004).

Again, new research effort to further address food insecurity in sub-Saharan Africa was initiated by the IDRC and the Australian Centre for International Research (ACIAR) under the Cultivate Africa's Future (CultiAF) Fund. The CultiAF was a four-year $\$ 15$-million partnership established by the two agencies to "support innovative research on post-harvest systems, nutrition, and sustainable water use ... identify ways to extend the reach of promising research results and support national and regional food security efforts in Africa" (IDRC/CRDI News, 2014). Accordingly; five projects were chosen for sponsorship, which covered researches on fish processing, fungi on maize, poultry, and Beans production in Zambia, Malawi, Zimbabwe, Kenya, and Uganda (See:IDRC/CRDI News 2014. 2 of 2).

Furthermore, in Nigeria, the application of research in science and technology to production of indigenous vegetables has tended to boost food security in the country. For instance, SciDevNet (2014) reported on how research projects aimed at training 1, 200 farmer in 22 cooperative groups in four southwestern states of Nigeria on how to sustainably grow and maintain vegetables vi-a-vis through radio programme; initiated for six indigenous vegetable ( namely: "African nightshade, eggplant, scarlet eggplant, local celery, fluted pumpkin and local amaranth - based on their food values, consumer acceptability, marketing potential and amenability to agronomic practices") has tended to improve their mean income from US\$1, 994 a year to US\$3, 376. This is a very distinctive contribution to sustainable food production in the country. The principal project investigator and director of research and linkages at the Osun State University, Odunayo Clement Adeboye asserts that "the awareness and gender training (that) have empowered women's access to resources" (SciDevNet, 2014). A Study (The World Bank, IRBD-IDA, 2014) on Ethiopia, Kenya, Tanzania and Uganda has demonstrated the utility of Science and Technology to boost Agricultural Productivity. The Study notes that successes were recorded in the following Schemes:

a. Tanzania, Nyatwali Irrigation Scheme: Assisted the high yielding cultivation of Rice in Nyatwali village.

b. Uganda, Winning the Battle against Brown Streak Disease: The effort of National Crops Resources Research Institute has checkmate the disease and consequently enhance for Cassava production.

c. Ethiopia, Tackling the Scourge of Yellow Rust: The Ethiopian Institute of Agricultural Research has developed new wheat varieties that are resistant to the disease and enhance higher productivity by the farmers.

d. Kenya, Meeting Surging Demand for Milk: Through initiative of the Kenya's Ministry of Agriculture, Livestock and Fisheries, new, healthy breeds, advanced insemination techniques and improved fodder quality that combines protein-rich crop residues have tended to increase the quality and productivity of livestock (for details; see : The World Bank, IRBD-IDA, 2014: 1-2).

Another strategic contribution of science and technology to food production in Africa is the adoption of what Filli et al., (2014) call Extrusion Technology (EC). Filli et al. argue that "if developing economies are to eradicate poverty and achieve food and national security, more effort is needed in harnessing extrusion technology for producing safe food utilizing locally grown legumes and cereal grains". According to these scholars, "extrusion is a process that combines several units operations, including mixing, cooking, kneading, shearing, shaping and forming (Riaz, 2013 cited in Filli et al. (2014).

Nevertheless, despite the above advances, the EC processes in Africa have a number of disadvantages which include: lack of consistent, uniform, quantity grain supplies, extension of existing processing technology is unavailable, governmental policy; and, subsidized maize price, etc. On the way forward, Filli et al. (2014) posits that the production of staples such as cereals, root and tuber, fruit crops and palms is required, improvement in producer access to new technology, innovative technology commercialization strategy, joint sponsorship of workshops, seminars and short-term training. Others include training and capacity building of both scientist and institutions, creation of links and working relationships with other agencies.

Also, Biotechnology has afforded the mechanism for ridding the world of rinderpest. Before now, FAO Documents posits that "this viral disease, ... affects cattle including buffalo, yak and related wildlife species, destroyed nearly 90 per cent of all cattle in sub-Saharan in the 1890s... between 1979 and 1983 killed more than 100 million head of cattle in Africa - more than 500000 in Nigeria alone...." Evidently, this loss tended to have negatively reduce availability of the much needed food in Nigeria. Indeed, collaboration of the Pan African Rinderpest Eradication Campaign (PARC), with the Global Rinderpest Programme (GREP) have substantially embattled rinderpest in Africa (FAO, 2004a).

Science and technology, especially biotechnology at first glance, seems to provide a panacea for the multiple 
socioeconomic, political problems that are associated with inadequate food supply. But what is the place of third world in general and Africa in particular as the science and technological crusade gathers momentum? The answer lies in the way the industrialized countries have manipulated these developments to suit their purpose.

The recent surge of Multinational Corporations (MNCs) has made it difficult for Africa to play a leading role in the preservation of biological diversity. These institutions because of their high capital and technology have lay claim to monopoly biotechnology and have been reaping profit from the sales of marketable products in total disregard of the condition of Africa. For example, pharmaceutical companies in the advanced countries have actively explored plants, microbes and other living organisms in the tropical forests of Africa for possible production of prescription drugs. Ten of the globe's 25 top selling drugs are derived from natural biological sources (UNEP, 2006:www.org. Assessed on 3 January, 18).

Biogenetical engineering of harvest threatens to disrupt established trade and profits because most transgenetically altered foods crops (primarily soybeans, beef, corn and cotton) derived from Africa are produced in the Advanced Countries and later exported to Africa at higher prices. For example Western Countries showed scant consideration for African crops, by charging very low prices. It is for this reason that prices of agricultural products (such as cocoa, coffee, rubber and cotton) fell so low that the continent was plunged into severe economic nightmare. Consequently, the cost of genetically modified products are so expensive for an average person on the continent who lives on less than a dollar a day to meet the expenses. In most cases, national governments usually assist her citizen through subsidization of agricultural production. But MNCs in collaboration with Western government and their financial institutions have continuously advise African government against subsidization even though such a policy exists in their home countries to protect their Industries (Stiglitz, 2002).

\section{Conclusion and Recommendations}

The study has graphically illustrated the enormous role that science and technology has or can play in achieving sustainable food security in Africa. However a number of challenges have identified. Efforts should aimed at addressing these challenges. Nevertheless, there is no doubt that new crops with improved characteristics created through genetic engineering have allayed fears of eminent food crisis in Africa and the world. The fundamental question which needs to be asked is, has Africa benefited commensurably from biotechnological revolution? This is given her enormous natural resources as inputs vis-à-vis the countries of the Western hemisphere, to the benefits of biotechnology, biosafety and biodiversity. It is that, the West are not oblige to transfer relevant agro-allied science and technology to Africa or is that incongruent policy formulation and implementation?

The following recommendations are hereby made:

First, the recommendations posited by Enete \& Amusa, 2010) are also accepted as pertinent for pursuing a realistic approach to achieve sustainable food production in Africa. (See i - iii below).

i. Efforts should be made to allay the fears of farmers with regards to the enactment of biosafety. For the farmers, the question was: question arises, what potential good could come from legalisation of GMOs food products in Nigeria? (Modification to the biosafety Act should initiated to take particular note of differences in Africa's ecosystem and products.

ii. Farmers should change their dawdling attitude to farming, practices such as bush burning, deforestation and rain-fed agriculture.

iii. There should be an explicit national agricultural policy framework, adequate provision for irrigation, drainage, weather forecasting and other agricultural technology infrastructure, an incentive for training in agriculture, participatory and on-going capacity building for farmers".

Other recommendations are:

iv. In order to reap the full value of science and technology vis-à-vis the achievement of food security, Africa must lay a solid foundation for African science and technology by investing more on education, research and development (R\&D), as well as initiate public policies aimed at sharing adaptive and practical innovations and breakthroughs in science, technology and sustainability of food in the African continent among African States.

v. African political leader must exhibit transparent and coherent will to formulate and implement comprehensive policy on sustainable food production. For instance, the strategy of Extrusion Technology should be principally adopted to boost food production on the continent.

vi. African countries should desist from unwholesome application of science, technology and innovations suggestively "imported" from abroad without considering the unique and distinctive character and attributes of their clime and agricultural products. 
vii. The issue of corruption should not overlooked. There are instances where funds earmarked for research and development are misappropriated with impunity. Such social vice and its related offences should be monitored and sufficient action taken to checkmate them.

viii. Where appropriate, indigenous science, technology and innovation practices should adopted, and adapted to agricultural production, as these would contribute immensely to ensuring sustainable food security in Africa.

\section{References}

Alhassan, W. S. (2003). The Case for Biotechnology in Africa's Agriculture. Knowledge for Development. CTA, Wageningen. The Netherlands. Retrieved from: https://cgspace.cgiar.org/handle/10568/63792. Assessed on 4 May, 20015

Andersen, P. P. (2002). Food and Agricultural Policy for a Global World: Preparing for the Future. Amer. J. Agr. Econ. 84, No. 5. Proceedings Issues December, pp 1214 -1214. American Agricultural Economists Association.

Bartel, C. (2010). Enhancing Food Security in Africa through Science, Technology and Innovation. Summary of UNCTAD Technology and Innovation Report 2010. Retrieved from http://www. atdforum.org/journal/htm/2009-34/11/... Assessed on 10/02/2015

Biosafety and the Environment: An Introduction to the Cartagena Protocol on Biosafety (PDF). GE.03-01836/E. United Nations Environment Programme. p. 8. Retrieved from: http://www.cbd.int/doc/press/presskits/bs/cpbs-unep-cbd-en.pdf. Assessed on 20 May, 2015.

Clark, N., Mugabe, J. \& Smith, J. (2005) Governing Agricultural Biotechnology in Africa: Building Public Confidence and Capacity for Policy-Making. African Centre for Technology Studies Press, Nairobi, Kenya.

Clark, N., Stokes, K. \& Mugabe, J. (2002). Biotechnology and Development: Threats and Promises for the 21st century. Futures, 34(910), pp. $785-806$.

Coker, M. A., Obo, U. B. \& Ugwu, U. (2013). Managing Sustainable Development in Our Modern Cities: Issues and Challenges of Implementing Calabar Urban Renewal Programmes, 1999 - 2011. Asian Social Science. Volume 9. No. 13 October: 74 - 84

Cyrus G. Ndiritu. C. G. (2012). Kenya: Biotechnology in Africa: Why the Controversy? http:/library.cgiar.org/bitstream/handle/ $10947 / 5594 /$ Ndiritu.pdf?sequence=1

Development 56, 266-273 (June 2013) doi:10.1057/dev.2013.27. Retrieved from: http://www.palgrve-journals.com/developmentjournal/ v56/n2/full... Assessed on 20 May, 2015

Don Ihde, (1999). Expanding Hermeneutics: Visualism in Science. Northwestern University Press, p. 8. James M. M. Good, (Cited in Wikipedia, Retrieved from: https://en.wikipedia.org/wiki/Technoscience. Assessed on 10th June, 2015

Doyle, J. \& Persley, G. (1996). "Enabling the safe use of Biotechnology: Principles and Practice". Environmentally sustainable studies and monographs. Series No. 10, Washington DC: World Bank.

Enete, A. A. \& Amusa, T. A. (2010) Challenges of Agricultural Adaptation to Climate Change in Nigeria: A Synthesis from the Literature », Field Actions Science Reports [Online], Vol. 4 | 2010, Online since 20 December 2010, Connection on 12 October 2012. URL: http://factsreports.revues. org/678 Assessed on 7 June, 2015.

Essegbey, G. and Strokes, K. (1998). Building Capacity for Biosafety Policy in Ghana: Issues and Options for Policy Makers". Journal of Science Technology and Development, VOL 16 (2) cited In: Clark, Norman; Stokes, Kathryn and Mugabe, John (2002). Biotechnology and development: threats and promises for the 21st century. Futures, 34(9-10), pp. 785-806.

Essiet, D. (2014). Unleashing Science \& Technology, to Boost Food Security, Job Creation Retrieved from: ttp://thenationonlineng.net/ unleashing-science-technology-innovation-to-boost-fo... Assessed on 20 August, 2015

FAO Corporate Document Repository (2014a). Chapter 1. What is Agricultural biotechnology? The State of Food and Agriculture, 2003 2004. Produced by: Economic and Social Development Department. Retrieved from http://www.fao.org/docrep/006/y5160e07. htm. Assessed on 28/08/2105

FAO Corporate Document Repository (2014b). Chapter 2. Agriculture, food security and nutrition. The State of Food and Agriculture, 2003 - 2004. Produced by: Economic and Social Development Department. Retrieved from: http://www.fao.org/docrep/006/ y5160e07.htm. Assessed on 28/08/2105

Filli, K. B., Jideani, A.O., Jideani, V. A. (2014). Extrusion Bolsters Food Security in Africa. IFT. Org. http://www.ift.org/foodtechnoology/past-issues/2014/april/feature/extension.

Gaston Bachelard (1953). La materialisme rationel, Paris: PUF. (Cited in Wikipedia: Retrieved from: https://en.wikipedia.org/wiki/ Technoscience. Assessed on 10th June, 2015.

Good, J. M. M \& Velody, I. (1998). The Politics of Postmodernity, Cambridge University Press. (Cited in Wikipedia, Retrieved from: https://en.wikipedia.org/wiki/Technoscience. Assessed on 10th June, 2015.

Gugliotta, G. (2004). Scientists Say Warming to Increase Extinction. In: Grimmett R. (ed). The State. Columbia S.C. January, 8.

IDRC/CRDI News (2004) New Research to address food insecurity in Sub-Saharan Africa (2014) Retrieved from http://www.idrc.ca/EN/ Misc/Pages/NewsDetails.aspx\%3FNewsID\%3D697. Assessed on 17 August, 2015

IFPRI (International Food Policy Research Institute). 2002. Reaching sustainable food security for all by 2020. Getting the priorities and responsibilities right. Washington, D.C: IFPRI

Kabeba, M. R. (2012). Strengthening Institutional Capacity for Science, Technology and Innovation in Uganda. Theoretical and Methodological Approaches to Social Sciences and Knowledge. Management Retrieved from: http: I/cdn.intechopen.com /pdfs/38294/InTech-Strengthening_institutional_capacity_for_science_tec. 
Kalep Bulus Filli, Afam I. O. Jideani, Victoria A. Jideani, April 2014 Extrusion bolsters Food Security in Africa. IFT. Org. Retrieved from:http://www.ift.org/food-technoology/past-issues/2014/april/feature/extension... Assessed on 4/8/2015

Kegler, C. W. (2007). World Politics: Trends and Transformation. Canada, Mexico: Thomson Wadsworth.

Kherallah et al. (2002). Reforming Agricultural Markets in Africa. IFPRI: The Johns Hopkins University Press.

Lukpata, V. I, Olurunfemi, A. \& Elimian, A. (2014). The Challenge of Bringing the Traditional Military Authority Structure in Nigeria in Line with Modern Technology. International Journal of Peace and Conflict Studies (IJPCS), Vol. 2. No. 1, March, pp 76 - 81

Morgan, P. (1979). Science and Technology Development: The Role of USA Universities. New York: Washington Universities.

Mwaniki, A. (2005). "Achieving Food Security in Africa: Challenges and Issues". Retrieved from: http//www.org. FSA.

Nang 'ayo, F. (2006). The Status of Regulation for Critically Modified Crops in Countries of the Sub-Saharan Africa. Africa Agricultural Technology Foundation

Ndiritu C. G. (2007). Kenya: Biotechnology in Africa: Why the Controversy: Retrieved from: http//www.org.Biotech.

Nigeria science, technology benefit from AfDB \$65m investment September 17, 2012 | Filed under: Lead Stories, Regional | Posted by: AfricaSTI. Retrieved from: http://www. africasti.com/lead-stories/nigeria-science-technology-benefit-from-afdb-65m-investment

Nigeria science, technology benefit from AfDB $\$ 65 \mathrm{~m}$ investment. Africa Science Technology \& Innovation News Retrieved from: http://www.africasti.com/lead-stories/nigeria-science-technology-benefit-from-afdb-65m-investmen... Assessed on 12 May 2014.

Njemanze, P. (2015). Biosafety bill: A danger to food security and health file:///C:/Users/delecoker/Desktop/Biosafety\%20bill\%20\% $20 \mathrm{~A} \% 20$ danger\%20to\%20food\%20security\%20and\%20health.htm

Nkama, I. and Filli, K.B. 2006. Development and characteristics of extruded fura from mixtures of pearl millet and grain legumes flours. Intl. J. Food Properties 9: 1-9.

Oehmke, F. F., Maraedia, M. M. \& Weather, D. D. (2001). The Effects of Biotechnology Policy on Trade and Growth". The Estey Centre Journal of International Law and Trade Policy. Vol. 2(2).

Oke, M.O., Awonorin, S.O., and. Workneh, T.S. 2013. Expansion ratio of extruded water yam (Dioscorea alata) starches using a single screw extruder. AJAR 8(9): 750-762.

Oluwole, O.B., Awonorin, S.O., Henshaw, F., Elemo, G.N., and Ebuehi, O.A.T. 2013. Assessment of microbial changes and nutritional qualities of extruded white yam (Dioscorea rotundata) and bambara groundnut (Vigna subterranean) blends. Food Nutri. Sci. 4: 100-107. Cited in: Filli, K. B., Jideani, A.O., Jideani, V. A. (2014). Extrusion Bolsters Food Security in Africa. IFT. Org. http://www.ift.org/food-technoology/past-issues/2014/april/feature/extension.

Oxford Advanced Learner's Dictionary.

Ozor, N. \& Urama, K. (2013). The Role of Technology in Ensuring Adequate Food Security in Africa. Local/Global Encounters.

Productivity. Retrieved from: http://www.worldbank.org/en/news/feature/2014/07/10/ethiopia-kenya-tanzania-... Assessed on 16 June, 2015.

Quaim, M. (1999). The Economic Effects of Genetically Modified Orphan commodities. Projection for Sweet Potato in Kenya. ISAAA Brief 13.

Rademacher, A. (2015). Food Insecurity in Sub-Saharan Africa. Topical Review Digest: Human Rights in Sub-Saharan Africa.

Ralloff, R. (2006). "The Ultimate Crop Insurance" In: Robert Griffiths (ed.) Global Issues. Dubuque McGraw-Hill, p. 157. Retrieved from: http://www.du.edu/korbel/researchdigest/Africa/Foodinsecurity.pdf.

Retrieved from: https://en.wikipedia.org/wiki/Technoscience. Assessed on 10th June, 2015.

Riaz, M. 2013b. Introduction to Extrusion. Presented at the ExtruAfrica Conference, "Needs, barriers and opportunities for extrusion in Africa", at Protea hotel Kruger Park, Skukuza Mpumalanga province, South Africa, August 1-2. Cited in: Filli, K. B., Jideani, A.O., Jideani, V. A. (2014). Extrusion Bolsters Food Security in Africa. IFT. Org. http://www.ift.org/food-technoology/past-issues/2014/ april/feature/extension.

Rosegrant, M. W., Sarah A. C., Weibo Li, Timothy B. S., and Rowena A. V..(2005). Looking Ahead: Long-term Prospects for Africa's Agricultural Development and Food Security. 2020 Discussion Paper No. 41. Washington, D.C.: International Food Policy Research Institute.

Rourke, T. J. (2005). International Politics on the World Stage. New York: Mc Graw-Hill.

SciDev.Net (2003) Science brings optimism to African food security. Retrieved from: $h$ ttp://www.scidev.net/golbal/opinion/science-bringsoptimism-to-af... Assessed on 5 June 29, 2015

SCiDevNet (2-14) Indigenous Vegetables Boost Food Security in Nigeria. Retrieved from: http://www.scidev.net/sub-saharan-africa/foodsecurity/news/indigenous-veg. Assessed on 12 July, 2015

Science. Online Etymology Dictionary. Retrieved From: http://www.etymonline.com/index.php\%3Fterm\%3Dscience. Assessed on 20 September 2014.

Status of Agricultural Biotechnology and Biosafety Regulatory Systems in East Africa: Agricultural Biotechnology Research and Development Retrieved From: http://www.biovisioneastafrica.com/publications/status_biosafety_biotech.pdf. Assessed on May 2015.

Stighitz, J. (2002). Globalization and its Discontents. Canada: Penguin Books,

The World Bank, IBRD-IDA (2014). Ethiopia, Kenya, Tanzania and Uganda Use of Science and Technology to boost Agricultural

Thomson, B. A. (2004). "The status of plant Biotechnology in Africa". The Journal of Agro biotechnology, Management and Economics, Vol. 7.

What is Engineering Science? Retrieved from: http://www.engineering-science.org/wp-content/themes/iesc/pdf/activity_report/ppt_ material_3.pdf. 